\title{
DESTINATION DEVELOPMENT MODEL FOR FOREIGN SENIOR TOURISTS
}

\author{
I Gusti Bagus Rai Utama, Putu Chris Susanto. \\ Universitas Dhyana Pura, Universitas Dhyana Pura \\ igustibagusraiutama@gmail.com,putuchrissusanto@gmail.com
}

\begin{abstract}
This study aims to produce a destination development model for foreign senior tourists, involving 400 respondents and 40 tourism professionals as informants. The concept and theory as the basis of confirmation is the totality of tourism product (4A), which consists of attractions, accessibility, amenities, and ancillary services. Senior tourists tend to seek cultural attractions, art performances, festivals, natural attractions, and fair prices such as ones found in traditional markets. For amenities, seniors expect certain amenities such as: places for rest and relaxation, new facilities, places to gain knowledge and experience, places to escape the daily routine, places to meet people and interact, and senior-friendly accommodations. In terms of accessibility, seniors expect the availability of local transportation, tourism infrastructure, senior-friendly airport facilities and services. For ancillary services, seniors expect to get proper guidance and assistance throughout their visit. For local communities, the development of tourism destination specifically geared to attract seniors has a sizeable implication on the availability of employment but is difficult to develop because the facilities and infrastructure involved require significant investment.
\end{abstract}

Keywords: attraction, accessibility, amenities, ancillary services, senior tourists, tourism destination

\section{Introduction}

The senior tourism segment has become increasingly important for the overall tourism industry due to the target market's purchasing power and availability of leisure time. Seniors also have the willingness for overseas travel, entertainment, and recreational activities. Based on this phenomenon, a supplemental research is necessary to identify and further analyze the strengths and weaknesses of the senior tourism segment from various aspects including economic aspects, social aspects, cultural aspects, and societal impacts. Upon learning the impacts of senior tourism on local communities, destination managers should determine the right product offering mix to minimalize the negative impacts of tourism development with senior tourists as the target market. Developers must identify the potential gains and losses of tourism on the local communities, specifically in terms of employment opportunities and the sustainability of tourism as a whole. This study aims to provide an important 
groundwork for tourism development model for senior tourism and communitybased tourism development because, at least theoretically, the development of tourism targeting seniors has a significant multiplier effect on the local community.

The limitations of the first and second stages of this three-step research process indicated the need to further the study into its third stage, particularly if Bali and Indonesia aim to capture the opportunity in the senior tourism market. The third follow-up research aims to provide confirmation on the findings from the first (2014) and second (2015) research stages.

The aim of the current study is to identify the potential advantages and disadvantages of senior tourism development for local communities, which has an implication on employment opportunities and the sustainability of tourism as a whole. This study provides an important stepping stone for the development of tourism management model for senior market, as well as for community-based tourism development that theoretically has a significant multiplier effect on the local communities in which the operate.

\subsection{Research Questions}

Based on the background information above, the main research questions of this study are as follows:

1) What are the advantages and disadvantages of the senior tourism market segment, analyzed from the economic, social, cultural, and societal impacts for local communities?

2) What implications do senior tourism have on employment opportunities and the sustainability of tourism as a whole?

3) What is the appropriate development/management model for senior tourism, based on community-based tourism development?

\subsection{Research objectives}

Based on the research questions formulated, the objectives of the current study are as follows:

1) To identify the advantages and disadvantages of the senior tourism market segment, analyzed from the economic, social, cultural, and societal impacts for local communities.

2) To identify the implications of senior tourism on employment opportunities and the sustainability of tourism as a whole.

3) To determine a sound development/management model for senior tourism, based on community-based tourism development.

\section{Theoretical Framework and Concept}

Tourists have different motivations for conducting their travel activities (Fandeli, 2001:41), which can be categorized into four motivational clusters: (1) physical motivation in the form of relaxation, health and wellness, sport, recreation, and romance; (2) cultural motivation in the form of desire to witness local customs and arts; (3) social motivation in the form of visiting friends and relatives, pilgrimage, and seeking new experiences in new environments (both physical and social); and (4) prestige motivation in the form of hobby, furthering study, meetings, conferences, and seminars. 


\subsection{Tourism Motivation}

Motivation comes from the word "motive", indicating something that that cause someone to perform an act in a certain way or something that stimulates desire. Further, Abraham Maslow created a hierarchical model of motivation known as the Maslow motivational theory. The Maslow model began with a basic psychological theory with the assumption that people will attempt to fulfil the most basic needs before anything else, i.e., fulfilling physiological needs before directing their behavior towards higher level needs such as self-actualization. The lower level needs should be fulfilled prior to higher level ones. For instance, if individuals decide that they have attained enough monetary rewards from their employers, then monetary rewards cease to have high motivational intensity on these individuals. When a certain need has reach its peak, that need ceases to be the main motivator of behavior. The second need will dominate. Even though the first need has been fulfilled, that need still affects behavior although with reduced intensity.

In the context of tourism, McIntosh dan Goeldner (in Pitana and Gayatri, 2005:52) differentiated tourist motivations into four categories:

1) Physical motivation, which refers to the motivation that relates to physical exercise, beach recreation, refreshing and rejuvenating activities, and other motivational profiles that directly relate to health and wellbeing.

2) Cultural motivation, which are motivational profiles that can be identified through the desire to know and experience a certain region, its music, art, folklore, dances, paintings, and religious customs.

3) Interpersonal motivation refers to motivational profiles that relate to the desire to meet new people, to visit friends and families, to step away from the daily routine, and to acquire new experiences.

4) Prestige and status motivation, which relates to attaining one's ego and self-fulfillment, for instance traveling for business, convention, study, hobby, and education. The desire for respect, attention, knowledge, and good reputation can be fulfilled throughout the duration of the travel.

In general, individuals seek a certain balance in their lives. Psychologically, the human need for life balance can be explained by the efforts to balance work and rest, activity and sleep, movement and relaxation, income and expenses, work and family, freedom and dependency, risk and rewards, as well as various social needs. Individuals have the tendency to break from their daily routines every now and again by conducting travel and tourism-related activities to refresh their bodies and minds, to regain vitality, and to give their lives a fresh new meaning (Krippendorf, 1987:47).

Based on Maslow's theory, travel and tourism activities can be motivated by the desire to improve health and well-being, including wellness tourism, medical tourism, and related activities. Travel and tourism activities can also be based on physiological needs, safety needs, esteem needs, as well as selfactualization needs. According to Huang and Hsu (2008: 267-287), there are human needs that do not belong to any of the five hierarchies set forth by Maslow. These needs include the need to engage in arts, the need of curiosity, and the need to be understood by peers. In fact, within the context of travel and tourism, these needs have significant impact on individuals' decision to engage in travel activities. 
The decision to conduct travel and tourism-related activities is influenced by push and pull factors, which are internal and external factors that motivate tourists in their travel decision making process. Sharpley (1994) and Wahab (1975, in Pitana and Gayatri, 2005:52) emphasized that motivational factors are the fundamental building blocks of tourism studies because motivation is the trigger of the travel and tourism process itself, even though tourists may not always be completely aware of their travel motivation.

\subsubsection{Push Factors for Tourism Activities}

Push factors are typically socio-psychological in nature, considered to be person specific motivational factors, while pull factors are considered to be destination specific attributes. By having push factors, individuals experience the desire to travel but have yet to decide which destination to visit. Ryan (1993, in Pitana and Gayatri, $2005: 61$ ), in his literature study found several push factors for engaging in travelrelated activities as follows:

a) Escaping boredom: the desire to release oneself from the mundane environment or to escape the overload of daily activities.

b) Rejuvenation: the desire to refresh and rejuvenate, which also relates to the escape motivation.

c) Enjoyment: the desire to experience happiness through various activities and games, which stems from one's innate childhood characteristics, and to detach oneself temporarily from adult and serious responsibilities.

d) Relationship and bonding: the desire to strengthen friendship and family bond, specifically in the context of visiting friends and relations.

e) Prestige: the desire to show off pride and prestige, by visiting specific destinations that indicate certain class and lifestyle, which also relates to the desire to increase social status.

f) Social interaction: the desire to involve oneself in social interaction with peers or with visited communities.

g) Romance: the desire to meet someone in a romantic manner or to fulfil sexual desires, particularly in sex tourism.

h) Culture: the desire to see and experience something new, to learn about other people, regions, cultures, and ethnicities. This is a dominant push factor in tourism.

i) Experience: the desire to find oneself, because one's true self can often be found when one is experiencing new areas or meeting new people.

j) Realizing dreams: the desire to realize one's dreams, which often involves saving up resources and sacrificing other needs in order to fulfil one's travel dreams.

Fundamentally, individuals conducting travel and tourism-related activities are motivated by a combination of several factors. These motivational factors can be categorized into four main categories: (1) Physical or physiological motivation, which refers to physical motivation such as to engage in sport, relaxation, and rejuvenation activities; (2) Cultural motivation, which relates to the desire to know other cultures, customs, tradition, and arts (3) Social motivation, which includes socially-driven motivational profiles such as visiting friends and relatives, meeting with work partners, engaging in travel activities considered to increase one's prestige, being involved in pilgrimage, escaping the 
daily routine, and so on; and (4) Fantasy motivation, which refers to the motivation to detach from one's mundane daily activities and to attain psychological satisfaction (McIntosh, 1977 and Murphy, 1985; in Pitana dan Gayatri, 2005:60).

Pearce (1998, in Pitana dan Gayatri) coined several motivational factors that influence tourists' travel decision making process: physiological needs, safety needs, social needs, prestige needs, and self-actualization needs. Meanwhile Jackson (1989, in Pitana dan Gayatri, 2005:62) perceived that the essential factors in determining the demand for tourism lie in geodemographic characteristics of tourists' area of origin, including but not limited to: population size, financial means, availability of leisure time, transportation system, and the available tourism marketing system.

From the reviewed literatures, the current research suggests that push factors for tourism can be predicted from the population size of the country-oforigin, its per capita income, the length of leisure time allocated for it citizens, the advancement of information technology and transportation infrastructure, welldeveloped tourism marketing system, social and political stability, as well as other aspects that relate to the physical and non-physical attributes of tourists.

\subsubsection{Pull Factors for Tourism Activities}

Several pull factors possessed by a tourism destination will draw tourists to visit a certain destination to fulfil their needs and desires. Medlik (1980) and Jackson, 1989 (in Pitana and Gayatri 2005:62 identified several pull factors and differentiated them into eleven motivational factors including: (1) destination climate, (2) tourism promotion, (3) advertising, (4) marketing efforts, (5) special events, (6) discounts, (7) friends to visit, (8) relatives to visit, (9) tourism attractions, (10) culture, (11) natural and created environment. Further, four aspects must be considered in a tourism destination's offering. These aspects are as follows:

a) Destination appeal; refers to the attributes of a tourism destination in any shape or form that can attract visitors. Every destination has a different appeal for tourists, in terms of natural beauty, culture, or customs.

b) Transportation or accessibility; refers to the attributes of a tourism destination that relate to the physical access for domestic and overseas tourists, both relating to the ease of access to reach the destination and ease of access for various attractions within the destination.

c) Main and supporting facilities; relate to the attribute of amenities as the precondition of a tourism destination so that visitors can feel comfortable spending an extended period of time in said destination.

d) Tourism institutions; relate to the human capital attribute of tourism, as well as the system and the institution of tourism in a destination, typically in the form of a tourism governing body/chamber supporting the development of the tourism destination. This aspect also includes the support of local law enforcement agencies, destination management agencies, and other supporting institutions that can create the sense of comfort and safety for tourists.

Smith (1988, in Pitana and Gayatri, 2005:62) further classified the various goods and services to be provided by a tourism destination into six main 
categories: (1) transportation, (2) travel services, (3) accommodation, (4) food services, (5) activities and attractions (recreation, culture, entertainment), and (6) retail goods.

A successful tourism destination offering should be able to explicate what is being offered, the attractions within the destination, the facilities available, and the agents or agencies to be contacted for purchasing the travel packages being offered.

\subsection{The Impact of Developing Senior Tourism on Local Communities}

From the economic perspective, the positive effects of tourism, using Bali Indonesia as the basis of case study, are as follows: (1) tourism increase the nation's foreign currency reserves through currency exchanges occurring in the tourism destination, (2) tourism provides lucrative market potential for local-made products and services, (3) tourism increases the income of local communities, both for individuals directly working in and those indirectly affected by the tourism sector, (4) tourism widens the opportunity for employment and job creation, for sectors immediately related to tourism (such as hotels, restaurants, and travel agencies) as well as for sectors indirectly related to tourism (such as arts and crafts producers, suppliers of produce, cultural attractions, retail, and other services), (5) tourism increases the local income in real terms, and (6) tourism stimulates creativity of artists, artisan communities, and craft makersincluding traditional musicians who perform specifically for tourism related activities (Antara, 2011).

\section{Research Methods}

\subsection{Location, and Design of Research}

This research is located in the Province of Bali, which offers a diverse tourism destination to a diverse group of nationalities (Disparda Bali, 2010). The determination of the senior tourists segment as the research object is based on the immense potential that this target market has for Bali.

\subsection{Scope of Research}

The scope of this study is tourism research using systemic approach, which refers to the approach that considers the movement of tourists, the communities that facilitate tourism, and the implications of both on the lives of the society at large create one interrelated unit in a "linked system" in which each component affect each other. Each movement of tourists into and within a destination will be followed by the provision of tourism facilities, and the interaction of both will create a logical influence for society in terms of economic, cultural, ecological, and political aspects. Therefore, a linked system of tourism is stimulated by the dynamics of its subsystems, such as the market, product, and marketing of tourism-especially for the senior tourism segment.

\subsection{Identification of Research Variables and Operational Definitions}

The current study is a continuation of previous research that uses the mixed methods (quantitative and qualitative) to confirm various indicators that make up the advantages and disadvantages of the senior tourists segment from the 
economic, social, cultural, and societal impacts for local communities. The current study also aims to confirm the implications of senior tourism on the availability of employment opportunities and the sustainability of tourism in general. Ultimately, the study aims to determine a sound model for tourism development and management specifically designed for senior tourism based on community-based tourism.

\subsection{Determination of Data Source}

The source of data in this study comes from primary research in the form of direct responses by respondents (i.e., foreign senior tourists) and informants (i.e., tourism operators specifically hoteliers and other providers of accommodations for the senior market segment).

\subsection{Sample}

This study was conducted using the census method by including all the population as sample. Response tolerance on the feedback was determined to be $30 \%$ of all population, or 50 informants and 400 senior tourist respondents.

\subsection{Research Instrument}

The instrument in this study is the interview guideline, which includes a list of questions to be asked by the researcher and the answers given by the informants.

\subsection{Data Collection Technique}

The data collection technique utilized in this study is semi-open survey, which is a data collection technique that involves providing semi-open survey questions asking about the advantages and disadvantages of the senior tourists segment based on its economic, social, cultural, societal impacts for local communities, and the types of employment opportunities necessary to serve the senior tourists segment.

\subsection{Data Analysis}

The research questions are analyzed using a mixed method of quantitative and qualitative statistical methods. The mixed method aims to form a complete picture of the advantages and disadvantages of the senior tourists segment based on its economic, social, cultural, and societal impacts for local communities. Then, the analysis continues by discussing the necessity for specific employment opportunities to serve the senior tourists segment. According to Moleong (2010:248), the steps of qualitative data analysis must begin with reading the data, then marking keywords and key ideas in the data. The next step involves studying the keywords to find recurring themes from the dataset. By creating a list of keywords, the researcher can then attempt to signify those keywords and to adjust the model that has been formed by the quantitative analysis.

In the current study, quantitative analysis is used to complement the qualitative analysis by using descriptive statistical analysis in the form of tables and graphs to visualize the research findings. Ultimately, the mixed method should determine a sound model of destination development model for senior tourism that benefits the local community. 


\section{Findings and Analysis}

The term "senior tourists" refer travelers in the age group of 55 and above. This age criteria refers to the common term (i.e., "older tourists") used in the United States (Clench, in Petterson, 2006). The Indonesian government has determined that the senior tourism market as a lucrative target market for several reasons: the improvement in health science has allowed individuals to enjoy higher life expectancy, the increase in life expectancy significantly increases the number of seniors worldwide, seniors are often provided with substantial retirement income sustained by effective social welfare system, and as such seniors have higher spending power than their younger counterparts. The senior market segment are also often referred to as DINKS (Double Income, No Kids). The travel pattern for this segment is typically signified by much longer leisure time.

\subsection{Design of Destination Development Model for Senior Tourism}

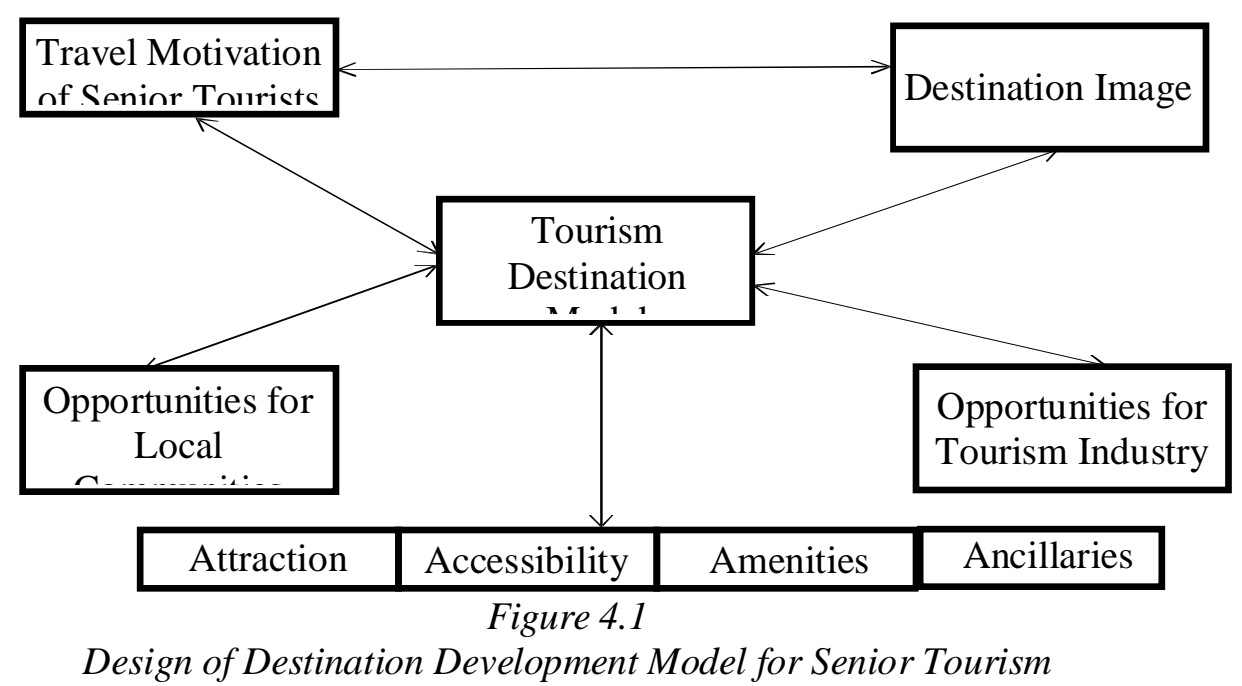

\subsubsection{Push Motivators for Senior Tourists}

The main push motivation of respondents (i.e., foreign senior tourists) to visit Bali is the rest and relaxation, as indicated by Table 4.1 .

Table 4.1

Respondents' Opinions on Push Motivational Factors

\begin{tabular}{clcccccc}
\hline Code & Indicator & $\mathrm{SD}$ & $\mathrm{D}$ & $\mathrm{N}$ & $\mathrm{A}$ & $\mathrm{SA}$ & $\%+$ \\
\hline $\mathrm{X}_{1.1}$ & Rest and relaxation & 6 & 8 & 28 & 148 & 210 & $90 \%$ \\
$\mathrm{X}_{1.2}$ & Visiting new places & 10 & 17 & 50 & 172 & 151 & $81 \%$ \\
$\mathrm{X}_{1.3}$ & Gaining experience and knowledge & 6 & 8 & 64 & 173 & 149 & $81 \%$ \\
$\mathrm{X}_{1.4}$ & Escaping the daily routine & 6 & 5 & 72 & 155 & 162 & $79 \%$ \\
$\mathrm{X}_{1.5}$ & Meeting people and socializing & 9 & 17 & 78 & 148 & 148 & $74 \%$ \\
$\mathrm{X}_{1.6}$ & Increasing health and wellness & 15 & 44 & 125 & 134 & 82 & $54 \%$ \\
$\mathrm{X}_{1.7}$ & Visiting family and friends & 55 & 47 & 87 & 106 & 105 & $53 \%$
\end{tabular}




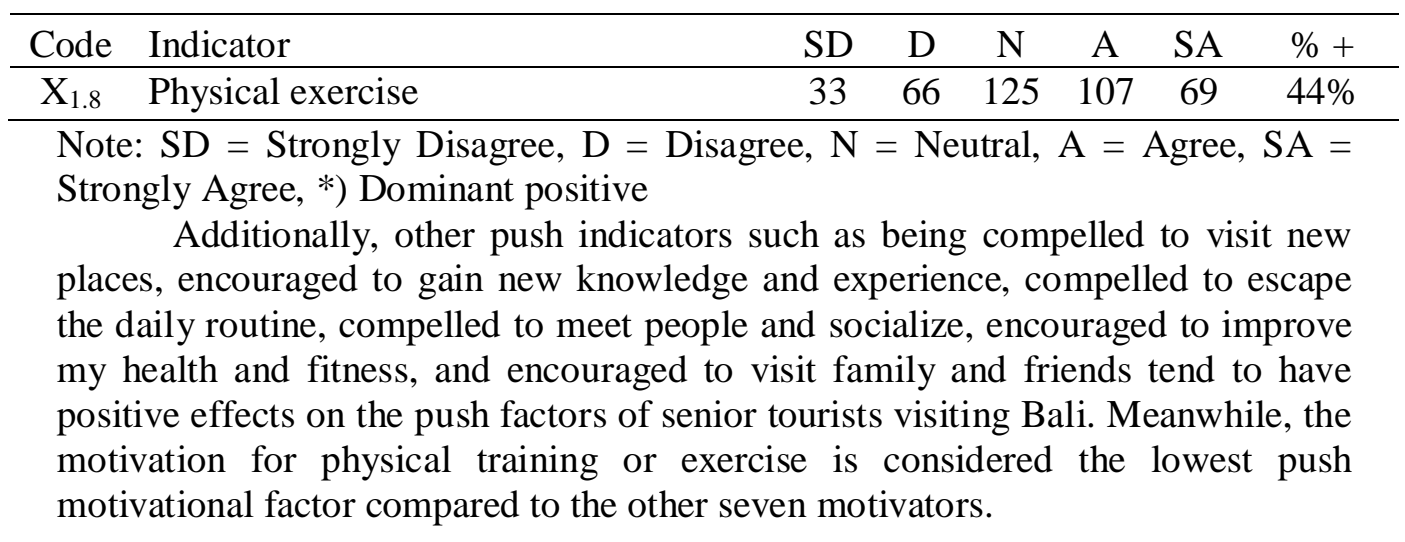

\subsubsection{Pull Motivators for Senior Tourists}

The strongest pull motivator for respondents (i.e., foreign senior tourists) to visit Bali is being interested in the culture of Bali, as indicated in Table 4.2. Other strong motivators include being interested in the history of Bali, nature of Bali, prices in Bali, various types of food and beverages available in Bali, events and festivals in Bali, as well as the keenness to take advantage of vacation or leisure time in Bali. Meanwhile, indicators such as being interested in the security of the island of Bali, in the health facilities in Bali, in the services of qualifies tour guides, in the quality travel agency services, and in the ease and service of the immigration procedures are found to be weak indicators of pull motivation for foreign senior tourists visiting Bali.

Table 4.2

Respondents' Opinions on Pull Motivational Factors

\begin{tabular}{llcccccc}
\hline Code & Indicator & SD & D & N & A & SA & $\%+$ \\
\hline $\mathrm{X}_{2.1}$ & Culture of Bali & 3 & 5 & 41 & 140 & 211 & $88 \%$ \\
$\mathrm{X}_{2.2}$ & History of Bali & 3 & 10 & 52 & 142 & 193 & $84 \%$ \\
$\mathrm{X}_{2.3}$ & Nature of Bali & 3 & 12 & 48 & 127 & 210 & $84 \%$ \\
$\mathrm{X}_{2.4}$ & Prices in Bali & 2 & 8 & 77 & 148 & 165 & $78 \%$ \\
$\mathrm{X}_{2.5}$ & Event and Festivals & 9 & 23 & 65 & 165 & 138 & $76 \%$ \\
$\mathrm{X}_{2.6}$ & Advantage of Leisure Time in Bali & 6 & 16 & 95 & 133 & 150 & $71 \%$ \\
$\mathrm{X}_{2.7}$ & Improvement in Transportation & 11 & 31 & 99 & 124 & 135 & $65 \%$ \\
$\mathrm{X}_{2.8}$ & Distance from Country-of-Origin & 23 & 24 & 110 & 133 & 110 & $61 \%$ \\
$\mathrm{X}_{2.9}$ & Balinese Culinary & 14 & 32 & 109 & 144 & 101 & $61 \%$ \\
$\mathrm{X}_{2.10}$ & Hotel Facilities and Services in Bali & 32 & 55 & 119 & 93 & 101 & $49 \%$ \\
$\mathrm{X}_{2.11}$ & Health Facilities in Bali & 31 & 44 & 136 & 115 & 74 & $47 \%$ \\
$\mathrm{X}_{2.12}$ & Immigration Services & 28 & 59 & 132 & 102 & 79 & $45 \%$ \\
$\mathrm{X}_{2.13}$ & Safety and Security in Bali & 29 & 52 & 144 & 95 & 80 & $44 \%$ \\
$\mathrm{X}_{2.14}$ & Quality of Tourism Agencies & 35 & 56 & 143 & 102 & 64 & $42 \%$ \\
$\mathrm{X}_{2.15}$ & Services of Qualified Tour Guides & 55 & 77 & 120 & 74 & 74 & $37 \%$ \\
\hline $\mathrm{N}_{2}:$ SD & D Strongly Disagree, D Disagree, N & & & & &
\end{tabular}

Note: $\mathrm{SD}=$ Strongly Disagree, $\mathrm{D}=$ Disagree, $\mathrm{N}=$ Neutral, A = Agree, SA = Strongly Agree 


\subsubsection{Destination Image According to Foreign Senior Tourists}

The quantitative descriptive depiction in Table 4.3 shows that indicator $\mathrm{Y}_{1.6}$ is a weak indicator for destination image, according to foreign senior tourists visiting Bali surveyed in this study, because the responses for this particular indicator tends to show the dominant mode of Disagree (D), Neutral (N), and Agree (A). On the contrary, indicator $\mathrm{Y}_{1.3}$ (the unique culture of Bali), $\mathrm{Y}_{1.1}$ (Bali as a destination for recreation and leisure), $\mathrm{Y}_{1.4}$ (friendliness of the Balinese people), $\mathrm{Y}_{1.5}$ (complete tourism infrastructure), $\mathrm{Y}_{1.2}$ (Bali as a natural destination), and $\mathrm{Y}_{1.7}$ (comfortable atmosphere) are strong indicators of Bali's destination image according to foreign senior tourists visiting Bali, because the responses tend to have high mode for the answer categories of Strongly Agree (SA) and Agree (A)-i.e., higher than $60 \%$.

Table 4.3

Frequency of Responses on the Destination Image Variable

\begin{tabular}{|c|c|c|c|c|c|c|c|}
\hline Code & Indicator & $\mathrm{SD}$ & $\mathrm{D}$ & $\mathrm{N}$ & A & $\mathrm{SA}$ & $\begin{array}{c}\text { Frequency of } \\
\mathrm{A} \text { and SA }\end{array}$ \\
\hline $\mathrm{Y}_{1.3}$ & The Unique Culture of Bali & 1 & 4 & 47 & 160 & 188 & $87 \%$ \\
\hline $\mathrm{Y}_{1.1}$ & $\begin{array}{l}\text { Destination for Recreation and } \\
\text { Leisure }\end{array}$ & 4 & 15 & 63 & 155 & 163 & $80 \%$ \\
\hline $\mathrm{Y}_{1.4}$ & Friendly People & 4 & 12 & 71 & 144 & 169 & $78 \%$ \\
\hline$Y_{1.5}$ & $\begin{array}{l}\text { Complete } \\
\text { Infrastructure }\end{array}$ & 5 & 13 & 91 & 143 & 148 & $73 \%$ \\
\hline $\mathrm{Y}_{1.2}$ & Natural Destination & 10 & 38 & 81 & 139 & 132 & $68 \%$ \\
\hline $\mathrm{Y}_{1.7}$ & Comfortable Atmosphere & 3 & 22 & 105 & 140 & 130 & $68 \%$ \\
\hline$Y_{1.6}$ & $\begin{array}{l}\text { Stability of Social and Political } \\
\text { Condition }\end{array}$ & 14 & 60 & 123 & 145 & 58 & $51 \%$ \\
\hline
\end{tabular}

Note: $\mathrm{SD}=$ Strongly Disagree, $\mathrm{D}=$ Disagree, $\mathrm{N}=$ Neutral, $\mathrm{A}=$ Agree, $\mathrm{SA}=$ Strongly Agree

\subsubsection{Market Opportunities for Tourism Industry}

To capture the market opportunities that lie within the rapid growth of the senior tourism segment, destinations must create and innovate an array of product offerings that meet the needs and preferences of senior tourists. Senior-friendly destination management must include the provision of infrastructure and facilities specifically geared towards providing access and comfort for senior tourists.

For the tourism industry, the accommodation facility suitable for seniors is budget luxury accommodation, three-star hotels and lodging that offer comfort and facilities with senior guests in consideration. A majority of senior tourists tend to favor internationally recognized hotels. However, some senior tourists also choose the types of accommodation already bundled in the travel package that they purchase.

Facilities expected by senior tourists include comfortable rooms with special facilities and consideration for seniors. Another finding suggests that several hotels specifically designed to accommodate people with disabilities also appeal to senior tourists. Seniors expect health facilities and guidance to be available throughout their stay. In terms of transportation, seniors prefer 
comfortable private rental cars. For long distance travels, they prefer to travel by air. Many seniors also use the facilities of travel and tourism agencies in the form of travel packages.

\subsubsection{Opportunities for Local Communities}

The main motives for senior tourists to visit Bali tend to be influenced by the culture of Bali, the fair prices in Bali, friendly locals, complete tourism facilities and infrastructure. Some tourists even consider Bali their second home. Senior tourists tend to express satisfaction of their experiences vacationing in Bali. In terms of their willingness to recommend Bali as a tourism destination, seniors tend to be in favor due to the friendliness of the locals, fair prices, and the available tourism infrastructure. Bali's tropical climate is often cited as a reason for recommending Bali as a tourism destination for friends and family.

For local Balinese communities, the development of senior tourism has an implication on the availability of employment opportunities and the sustainability of tourism as a whole, specifically in terms of the development of communitybased tourism-which has great multiplier effect for local communities. The opportunities to be captured by Balinese local communities, which already have the reputation as friendly and accommodating people as well as cultured and tolerant society, include providing guidance and services for senior tourists, cultural and art shows, culinary experience, and other services. 


\subsection{Destination Development Model for Senior Tourism}

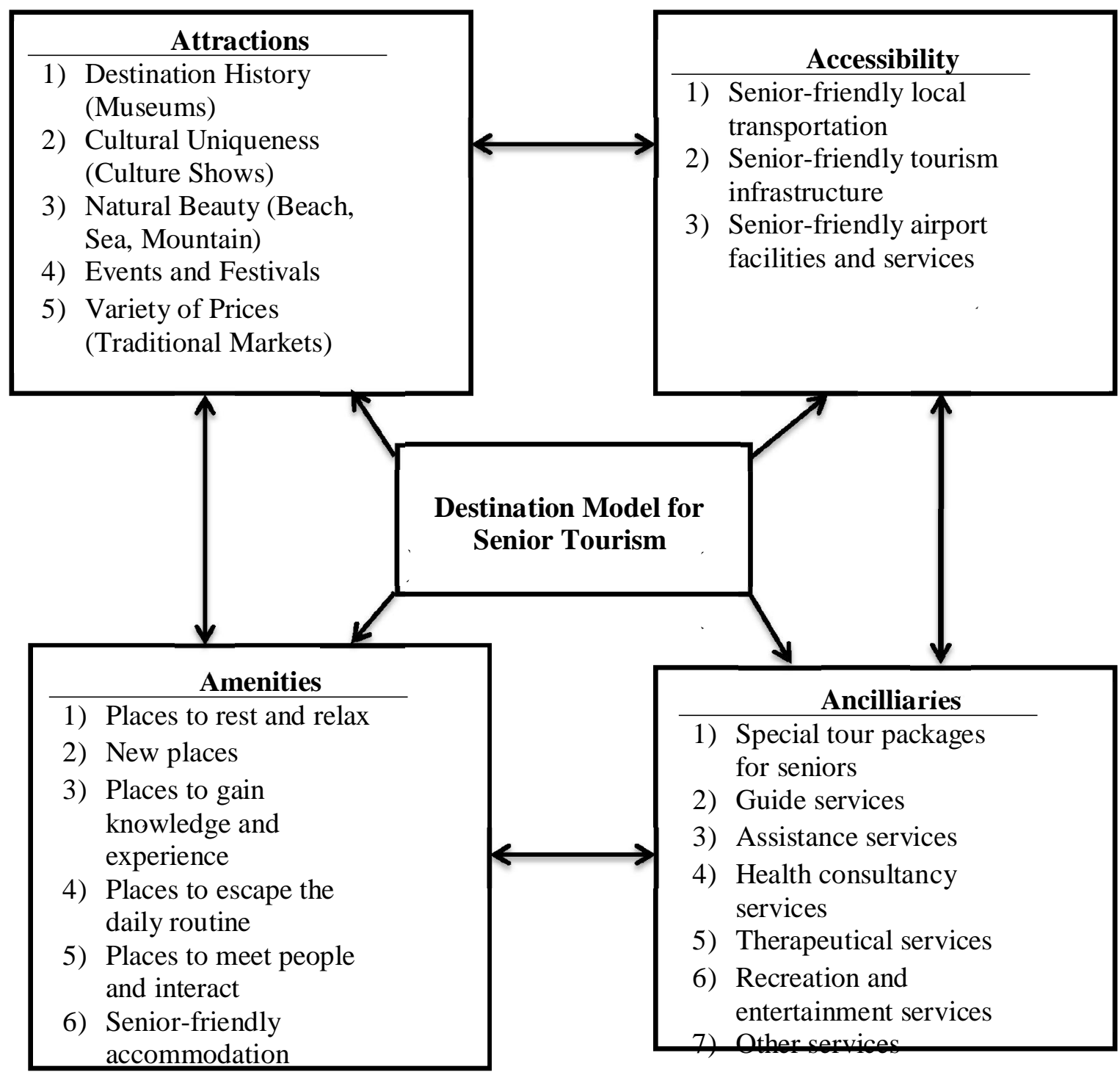

Figure 4.2

\section{Destination Model for Senior Tourism}

\section{Conclusion and Recommendations}

To capture the market opportunities that lie within the growth of the senior tourism segment, destinations should create and innovate tourism-related businesses and product offerings that cater to the needs and preferences of senior tourists. Senior-friendly destination management must include the provision of infrastructure and facilities that can be enjoyed by seniors. To create the right tourism innovation, research on the behavior senior tourists as tourism consumers is warranted. 
The destination model for senior tourism based on the research conducted can be described as follows:

The destination model expected by seniors include the appeals of cultural tourism, art performances, festivals, natural beauty, and the availability of variable and fair prices such as in traditional markets. In terms of amenities, seniors expect that a destination already provides amenities such as: places to rest and relax, new places, places to gain knowledge and experience, places to escape the daily routines, places to meet people and interact, as well as senior-friendly accommodation facilities. When it comes to accessibility, seniors expect the availability of senior-friendly local transportation, tourism infrastructure, and airport services. In terms of ancillary services, senior tourists have different expectations when compared to tourists from other age groups. Seniors expect the provision of senior-specific tour packages, guide and assistance services, health consultation services, therapeutical service, and other services.

The study conducted indicates that accommodation services and various other services specifically geared towards senior tourists have been limited and have not become a priority for tourism operators, because the operators consider that the senior tourism segment is a small segment for Bali as a destination. Conversely, the investment required to capture this market segment is significant.

Locals also assume that senior tourists are no different than any other tourists. As such, there is no need to treat senior tourists in a special manner. For local communities, however, the development of senior tourism destinations could have a great implication on the availability of employment opportunities and the sustainability of tourism in the area as a whole, specifically when the tourism development is community-based. In reality, community-based tourism is very difficult to develop and implement due to the significant investment required for facilities and infrastructure, for instance providing senior-friendly accommodation that share many similarities to providing disabled-friendly accommodation. Additionally, providing healthcare services for senior tourists in accordance to international standard is also prohibitively expensive for the local communities.

In terms of destination image, the ability of a destination to satisfactorily give optimum service for seniors could have a positive impact on the destination's international image. As such, the role of government is necessary to capture the market opportunities of senior tourists. The government's role include the provision of facilities and infrastructure, the improvement of immigration services and friendly airport services, as well as other conveniences specifically designed with senior tourists in mind.

\section{Acknowledgement}

The authors thank the Indonesian Ministry of Research, Technology, and Higher Education (Ristekdikti) that has provided the grant necessary (from 2014 to 2016) to conduct this research on destination development model for senior tourism. The authors also thank Universitas Dhyana Pura, specifically the Chair of Research and Community Development at the university. 


\section{REFERENCES}

Anonymous. 2012. Overall Tourist Satisfaction Index. The Hong Kong Polytechnic University, PolyU Tourist Satisfaction Index Report, retrieved from http://hotelschool.shtm.polyu.edu.hk/tsi/common/methodology.jsp on 23 October 2012

Antara, I Made. 2002. Metodologi Penelitian. Modul Metodologi Penelitian Pascasarjana Agribisnis. Universitas Udayana.

Antara, M, Pitana, G. 2009. Tourism Labour Market in the Asia Pacific Region: The Case of Indonesia. Paper Presented at the Fifth UNWTO International Conference on Tourism Statistics: Tourism an Engine for Employment Creation. Held in Bali, Indonesia, 30 March - 2 April 2009.

Antara, M. 2009. Pengembangan Museum Budaya Terpadu Sebagai Daya Tarik Wisata Kota Surabaya. Unpublished manuscript.

Ardika, I Wayan. 2003. Pariwisata Budaya Berkelanjutan, Refleksi dan Harapan di Tengah Perkembangan Global. Program Studi Magister (S2) : Postgraduate Study in Tourism, Udayana University.

Badan Pusat Statistik. 2011. Data Kunjungan Wisatawan Mancanegara dan Nusantara yang langsung datang ke Bali. BPS Prov Bali.

Chi, Gengqing. 2005. A Study of Developing Destination Loyalty Model. Submitted to the Faculty of the Graduate College of the Oklahoma State University in Partial Fulfillment of the Requirements for the Degree of Doctor of Philosophy, July 2005

Cooper, C. And Jackson, S. L. 1997. Destination Life Cycle: The Isle of The man Case Study. (ed. Lesly, France) in The Earthscan Reader in Sustainable Tourism. UK : Earthscan Publication Limited.

Cooper, Chris, John Fletcher, Alan Fyall, David Gilbert, Stephen Wanhill.1998. Tourism: Principles and Practice. Practic Hall

Darsoprajitno, H, Soewarno. 2001. Ekologi Pariwisata,Tata Laksana Pengelolaan Objek dan Daya Tarik Wisata. Bandung:Angkasa

Departemen Kebudayaan dan Pariwisata. 2010. Karakteristik Wisatawan Mancanegara Menurut Kelompok Umur Tahun 2009.

Disparda Bali 2010. Data Kunjungan Wisatawan Mancanegara berdasarkan Kebangsaan. Denpasar.

Disparda Bali. 2012. Kunjungan Langsung Wisatawan Mancanegara ke Bali 
Berdasarkan Kebangsaan Tahun 2007-2011. Kanwil Dep. Kehakiman dan HAM Provinsi Bali

Esichaikul, Ranee. 2012. Travel motivations, behavior and requirements of European senior tourists to Thailand.Sukhothai Thammathirat Open University (Thailand), Vol. 10 No 2. Special Issue. Pp. 47-58. 2012

Fandeli, Chafid. 2001. Dasar-dasar Managemen Kepariwisataan Alam. Liberty. Yogyakarta.

Ferdinand, Agusty. 2002. Structural Equation Modeling Dalam Penelitian Manajemen. Semarang : BP UNDIP.

Liying, Zhou Tze dan Wang, Xiaolin. 2012. Tourist Satisfaction-based Tourism Destination Image Mode - TSS. Retrieved from http://www.ikk9.com/Thesis/Management/Tourist_Management/20100430/ 6286.html on 23 October 2012

Marpaung, Happy. 2002. Pengantar Pariwisata. Bandung: Alfabeta

Maslow A. 1954. Motivation and Personality. Harper and Row: New York, pp 80-106

McIntosh, R.W. dan Goeldner, C.R. 1986. Tourism: Principles, Practices and Philosophies, 5th ed. John Wiley \& Sons, New York.

McIntosh, Robert W dan Charles R goeldner. 1986. Tourism Principle, Practices and Philosophies. L John Wiley \& Sons. New York.

Pendit, Nyoman, S. 1999. Ilmu Pariwisata, Sebuah Pengantar Perdana. Jakarta: PT Pradnya Paramita, $6^{\text {th }}$. (revised) Edition.

Petterson, Ian.2006. Growing Older: Tourism and Leisure Behaviour of Older Adults. School of Tourism and Leisure Management University of Queensland, CABI.

Pitana, I Gde dan Gayatri, Putu G. 2005. Sosiologi Pariwisata. Penerbit Andi Yogyakarta.

Publikasi Kem. Kebudayaan dan Pariwiata RI. 2011. SK Menteri Kehakiman No. M-04-12.01.02/1998. Jakarta.Temporary Visa: Ijin Tinggal Wisatawan Senior .

Rahmawati, Indah Putu. 2011. Motivation and Behavior of Older People Assist Segmenting the Mature Market and Identifying Senior Tourist Expectation. Denpasar: Jurnal Kepariwisataan, STP Nusa Dua Bali, Volume 10 Nomor 2 September 2011, ISSN: 1412-5498, Hal 95-100 
Som, Ahmad Puad Mat dan Badarneh, Mohammad Bader. 2011. Tourist Satisfaction and Repeat Visitation; Toward a New Comprehensive Model. International Journal of Human and Social Sciences 6:1 2011

Songshan (Sam) Huang and Cathy H.C. Hsu. 2009. Travel motivation: linking theory to practice. The Hong Kong Polytechnic University, Hong Kong, China. VOL. 3 NO. 4 2009. International Journal Of Culture, Tourism and Hospitality Research

Spillane, James.1993. Ekonomi Pariwisata, Sejarah dan prospeknya. Yogyakarta: Kanisius.

Temporary Visa: Ijin Tinggal Wisatawan Senior. 2011. Jakarta: Publikasi Kem. Kebudayaan dan Pariwiata RI. 2011. Keputusan Presiden /Keppres No. 31/1998.

World Population Data Sheet. 2012. Population Reference Bureau. 1875 Connecticut Ave., NW, Suite 520, Washington, DC 20009 USA, retrieved from website: www.prb.org on 12 Desember 2012. 